\title{
Borehole Water Quality Assessment in Bekwarra, Nigeria
}

Odey Emmanuel Alepu ${ }^{1 *}$, Giwa Abdulmoseen Segun ${ }^{2}$ and Harrison Odion Ikhumhen ${ }^{1}$

${ }^{1}$ School of Civil and Environmental Engineering, Beijing Key Laboratory of Resource - Oriented Treatment of Industrial Pollutants, University of Science and Technology, Beijing, PR China

${ }^{2}$ State Key Joint Laboratory of Environment Simulation and Pollution Control, School of Environment, Tsinghua University, Beijing, PR China

\begin{abstract}
This study briefly discussed water hygiene condition in Rural Bekwarra Community. Based on the 5 selected parameters for the experiments, results showed that average permeate Fluoride was $1.6 \mathrm{mg} / \mathrm{L}, \mathrm{pH}$ of 7.8 , average Iron $\left(\mathrm{Fe}^{+3}\right)$ of $0.7 \mathrm{mg} / \mathrm{L}$, Lead $(\mathrm{Pb})$ of $0.02 \mathrm{mg} / \mathrm{L}$, and Total Dissolved Solids of $578 \mathrm{mg} / \mathrm{L}$. From the results, it showed that only $\mathrm{pH}$ had average value within the standard requirement for drinkable water in Nigeria. Thus, there is a considerable need for the treatment and recycling of borehole water in the community before use.
\end{abstract}

Keywords: Water treatment; pH; Bekwarra; Borehole water

\section{Introduction}

Water is one of the essential elements of human life as the body cannot survive longer than few days without adequate water [1-4]. As such, the need to ensure that individuals get access to clean water cannot be ignored. However, improved access to safe water in Nigeria remains slow due to several issues related to corruption that pervades every sector of the economy. Nigeria is the most populous country in Africa with an estimated population of over 170 million, growing annually at a rate of 2 percent [5]. The fast-growing population has not been accompanied by increase access to good water supply [6]. The gap between the areas that have access to safe water supply and those without has grown wider. Rural areas like Bekwarra are experiencing a decline in water supply during the dry season.

Lack of accurate data makes it difficul to determine whether Nigeria is making progress to meet its millennium development goals (MDGs) targets by 2015 [6]. Water infrastructure in Nigeria has suffered from many years of poor operation. Inefficien institutions and unsustainable public sector spending have contributed to poor access to good water. State water agencies (SWAs) are responsible for the supply of urban water while the local government authorities are responsible for the establishment and maintenance of rural water supply. Most rural areas depend on boreholes or hand-dug wells for the water system [7]. However, there is no guarantee about the hygiene condition of this kind of water supply. Many people in the rural areas suffer from several kinds of diseases due to poor hygiene conditions of their water supply.

At rural level, water supply and monitoring systems are still inadequate. Some villages have access to stream water only. One of the reasons is that civil society does not have access to relevant information needed to present to the state government for proper establishment of water system. However, four out of the 36 States in Nigeria including Cross River State water agencies are undergoing reforms by introducing service public private participation [6]. This reform was established under the aim of developing and managing water supply facilities within the state. However, some communities like Bekwarra in the northern part of Cross River Sate still suffer from the availability of good water system. This short study presents water conditions in Bekwarra Local Government Area of Cross River Sate Nigeria with appropriate test on the hygiene condition of borehole water in the area.

\section{Materials and Methods}

Water quality assessment was done using 5 water quality parameters which include Fluoride $\left(\mathrm{F}^{-}\right), \mathrm{pH}$, Iron $\left(\mathrm{Fe}^{+3}\right)$, Lead $(\mathrm{Pb})$,
Total Dissolved Solids (TDS). These 5 parameters were selected because of the availability of equipments for the test in the study area. The $\mathrm{pH}$ was measured using electometric $\mathrm{pH}$ measurement equipment which consists of meter and electrodes. Water samples were collected from frequently used bore well daily for 5 days and stored in the laboratory prior to use. The samples were analyzed by standard method [8]. All precautions were taken to prevent contamination of the samples and to ensure that the concentration of the samples did not change during sampling and analysis. Thelaboratory used for the experiment complies with NIS ISO 17025: 2005 standard for drinking water surveillance.

\section{Results and Discussion}

Fluoride test was used to access the quality of water recovered from the frequently used bore well for the period of 4 days experiments. The average fuoride value obtained from the process was $1.6 \mathrm{mg} / \mathrm{L}$ which is slightly above $1.5 \mathrm{mg} / \mathrm{L}$ the recommended value for drinkable water in Nigeria. The value can be acceptable considering the little differences from the result. Table 1 shows the result for the overall 4 days experiment for the 5 selected parameters.

Test for the presence of Iron in the water indicated high content of Iron with the average value $0.7 \mathrm{mg} / \mathrm{L}$ which is more than the acceptable value of $0.3 \mathrm{mg} / \mathrm{L}$. The high content of Iron and other tested heavy metals was suggested to be as a result of underground weathering activity in the study region. The area is a basement area with underlying igneous rocks.

Total Dissolved Solids was used to determine the water quality based on biological and physical processes. TDS is an indicator of status and quality of water body. Average value from the 4 days experiment was $553 \mathrm{mg} / \mathrm{L}$ which is high when compared with the standard requirement for borehole water in Nigeria $(500 \mathrm{mg} / \mathrm{L})$.

The $\mathrm{pH}$ generally determines the concentration of hydrogen ions in a solution. It is one of the most important factors that determine

*Corresponding author: Dr. Odey Emmanuel Alepu, School of Civil and Environmental Engineering, Beijing Key Laboratory of Resource - Oriented Treatment of Industrial Pollutants, University of Science and Technology Beijing, Xueyuan 30, Beijing 100083, PR China, Tel: +8615652933203; E-mail: lordodey1@yahoo.com

Received July 26, 2016; Accepted September 30, 2016; Published November 22, 2016

Citation: Alepu OE, Segun GA, Ikhumhen HO (2016) Borehole Water Quality Assessment in Bekwarra, Nigeria. Adv Recycling Waste Manag 2: $116 . \quad$ DOI: 10.4172/2475-7675.1000116

Copyright: () 2016 Alepu OE, et al. This is an open-access article distributed under the terms of the Creative Commons Attribution License, which permits unrestricted use, distribution, and reproduction in any medium, provided the original author and source are credited. 
Citation: Alepu OE, Segun GA, Ikhumhen HO (2016) Borehole Water Quality Assessment in Bekwarra, Nigeria. Adv Recycling Waste Manag 2: 116. DOI: $10.4172 / 2475-7675.1000116$

Page 2 of 2

\begin{tabular}{|c|c|c|c|c|}
\hline Parameters (mg/L) except pH & Day 1 & Day 2 & Day 3 & Day 4 \\
\hline pH & 7.8 & 7.6 & 7.9 & 8.1 \\
\hline Fluoride (F) & 1.6 & 1.8 & 1.4 & 1.8 \\
\hline Iron (Fe+3) & 0.7 & 0.9 & 0.5 & 0.6 \\
\hline Lead (Pb) & 0.03 & 0.01 & 0.04 & 0.01 \\
\hline Total Dissolved Solids & 560 & 501 & 581 & 672 \\
\hline
\end{tabular}

Table 1: Various results for the tested parameters during the 4-day experiment.

the quality of groundwater. From the results obtained, $\mathrm{pH}$ was the only parameter that had values within the standard required values in Nigeria (6.5-8.5).

\section{Conclusion}

In the study, 5 parameters (Fluoride, Lead, Iron, Total Dissolved Solids and $\mathrm{pH}$ ) were used to determine the quality of borehole well in Bekwarra Nigeria, results indicated that the quality of water is in "fair" category and are not fit as such for drinking. Based on the overall results and analysis, there is a considerable need for proper treatment of borehole water in this area to provide adequate water that will meet the standard guideline for drinkable water in Nigeria.

\section{References}

1. Valipour M (2013) Evolution of Irrigation-Equipped Areas as Share of Cultivated Areas. Irrigat Drainage Sys Eng 2: e114.

2. Valipour M (2014) Handbook of Drainage Engineering Problems. Published by OMICS Group eBooks 731 Gull Ave, Foster City, CA 94404, USA.

3. Valipour M (2015) Handbook of Environmental Engineering Problems Published by OMICS Group eBooks 731 Gull Ave, Foster City, CA 94404, USA

4. Yannopoulos SI, Lyberatos G, Theodossiou N, Li W, Valipour M, et al. (2015) Evolution of Water Lifting Devices (Pumps) over the Centuries Worldwide. Water 7: 5031-5060.

5. Al-Zayer F (2006) Annual Statistical Bulletin OPEC. Head, Data Services Dept., to the Press Conference launching the "Annual Statistical Bulletin 2006", at the OPEC Secretariat in Vienna, Austria, 13 September 2007.

6. USAID (2006) USAID E-Government Update: FY 2006

7. WaterAid (2007) Sanitation and Economic Development: Making an economic case for the MDG orphan.

8. APHA (1992) Standard Methods for the Examination of Water and Wastewater. American Water and Water works Association and Water Environment Federation. 1000: 1010-3500. 